\title{
Die gebruik van die Ou Testament in die volkslewe
}

\section{'n Ondersoek onder predikante en ander lidmate van die Gereformeerde Kerke in Suid-Afrika}

\author{
J.L. Helberg \\ Dept. Ou en Nuwe Testament \\ Potchefstroomse Universiteit vir $\mathrm{CHO}$ \\ POTCHEFSTROOM
}

H.F. van Rooy

Dept. Klassieke en Semitistiek

Potchefstroomse Universiteit vir $\mathrm{CHO}$ POTCHEFSTROOM

\begin{abstract}
The use of the Old Testament by Afrikaners. A survey among ministers and other members of the Gereformeerde Kerke in Suid-Afrika (the Reformed Churches of South Africa)

The aim of this study was to determine the use of the Old Testament by members of the Gereformeerde Kerke in Suid-Afrika and the way in which the Old Testament is applied to the contemporary situation. An empirical study was undertaken to determine the approach of members of these churches to the Old Testament. In the first part of the paper issues necessary to evaluate the empirical study are discussed, while the second part presents the results of the empirical study. It is clear from the survey that the Old Testament is not used to the same extent as the New Testament by the ministers and other members of these churches. The views of the ministers on the application of the Old Testament to the situation of the Afrikaners are more nuanced than those of the other members of these churches.
\end{abstract}

\section{Inleiding}

Die doel van die ondersoek wat in hierdie artikel beskryf word, is om vas te stel watter plek die Ou Testament by lidmate van die Gereformeerde Kerke in SuidAfrika (hierna GKSA) inneem en hoe die Ou Testament in die hedendaagse situasie toegepas word. Aangesien Israel as uitverkore volk en sy land as uitverkore land so ' $n$ belangrike plek in die Ou Testament inneem, word veral op sake soos volkskap en land gekonsentreer. Die probleem waarop veral gekonsentreer word, is of die genoemde lidmate genoegsaam besef dat die $\mathrm{Ou}$ Testament as $\mathrm{Ou}$ Testament gelees moet word. Dit beteken dat sake wat in die Ou Testament aan die orde kom, nie sommer direk op die hedendaagse situasie 
oorgedra kan word nie. Die gegewens uit die Ou Testament moet vanuit die vervulling in Christus benader word voordat gevolgtrekkings vir vandag gemaak word.

Om hierdie probleem te ondersoek, is 'n empiriese ondersoek onderneem waarin die benadering van lidmate van die GKSA tot die Ou Testament vasgestel is. Die artikel val in twee boofdele uiteen. In die eerste gedeelte word gegewens bespreek wat van belang is vir die beoordeling van die resultate van die empiriese ondersoek, terwyl die resultate van die empiriese ondersoek in die tweede gedeelte bespreek en beoordeel word. Om die benadering van die lidmate te beoordeel, word die plek wat die Ou Testament in die kanon van die kerk inneem, kortliks in die eerste gedeelte bespreek, asook wat die $\mathrm{Ou}$ Testament oor volkskap en land in verband met Israel leer (vir ' $n$ volledige bespreking van die verhouding tussen Israel en sy land, vergelyk Helberg, 1990). Verder word ingegaan op die wyse waarop die situasie deur die koms van Christus geraak is - 'n aspek wat verband hou met die benadering tot die sogenaamde Messiaanse gedeeltes van die Ou Testament. In die tweede gedeelte word die resultate van die empiriese ondersoek bespreek en beoordeel. Die wyse waarop die ondersoek gedoen is, word aan die begin van die gedeelte bespreek.

\section{Tersaaklike gegewens vir die beoordeling van die empiriese ondersoek}

\subsection{Die plek van die Ou Testament in die kanon van die kerk}

Die naam Ou Testament sê dat daar 'n wending in die openbaringsgeskiedenis ingetree het en dat die Ou Testament oud geword het. Bright (1967:16, 60-67, 69-72) wys op die devaluering van die Ou Testament wat in die geskiedenis van die kerk telkens na vore gekom het. Volgens Marcion is daar geen plek vir die Ou Testament in die Christen se kanon nie. Volgens Harnack was daar wel op 'n stadium vir die Ou Testament plek, maar nie nou meer nie. Volgens Friedrich Delitzsch is dit 'n misleiding om die God van die Ou Testament die Vader van Christene te noem. Vir Bultmann het die Ou Testament alleen plek omdat hy die gelowige leer van die mislukking van daardie bedeling en hom daardeur na die nuwe bedeling laat verlang (vgl. ook Helberg, 1983:23-24, 36). Bright (1967:201-202) wys daarop dat Christus self geen probleem met die Ou Testament gehad het nie en wys op die diskontinuïteit sowel as die kontinuiteit tussen die Ou en Nuwe Testament. Die Ou Testament self stel inderdaad die nuwe verbond in voonuitsig (Jer. 31:31-33) en die boek Hebreërs wys op die voortreflikheid van die nuwe verbond in vergelyking met die oue. Die ou verbond is in Christus vervul. Die vervulling kanselleer egter nie die ou verbond nie, maar laat dit sy volle betekenis kry. Die Christen moet die Ou 
Testament dus verstaan in die mate wat sy lewe deur die dood en opstanding van Christus nuwe, vervulde betekenis kry. Die vervulling raak Israel as uitverkore volk met ' $n$ beloofde land. Die Ou Testament is dus steeds deel van die kanon van die kerk en het 'n belangrike funksie om te vervul, maar daar moet altyd rekening gehou word met die verandering wat met die koms van Christus ingetree het.

\subsection{Die Messiaanse gedeeltes in die Ou Testament}

Die naam Messias kom van 'n Hebreeuse woord wat verwys na die salwing van 'n persoon vir 'n spesifieke amp of funksie. In die Ou Testament is veral priesters en konings so gesalf. Wanneer daar na Messiaanse verwagtings in die Ou Testament verwys word, dui dit op verwagtings wat verband hou met toekomstige verlossing en veral dan verlossing deur ' $n$ Messiaanse figuur. Die Messiaanse verwagtings is gewoonlik verbind aan die dinastie van Dawid. Wat die sogenaamde Messiaanse gedeeltes van die Ou Testament betref, word soms die fout gemaak om hulle los van die res van die Ou Testament te benader en om aan hulle ' $n$ betekenis toe te skryf los van wat dit vir die eerste hoorders of lesers beteken het. Hierdie betekenis word dan direk aan Christus verbind. Op hierdie manier word die spesifieke Ou-Testamentiese gedeelte losgemaak van sy eie konteks. Die Ou Testament ken wel eskatologiese verwagtings, maar hierdie verwagtings mag nie net aan die sogenaamde messias verbind word nie (vgl. Helberg, 1988:166).

\subsection{Israel se volkskap in die Ou Testament}

\subsubsection{Die naam Israel}

Die naam Israel wys op die volk Israel as nasionale entiteit, maar is tog primêr 'n godsdienstige begrip en dui eintlik die verbondsvolk of Godsvolk aan. Jesaja 40 e.v. gebruik die naam Israel dan ook parallel met "my volk" en met "Jakob" $(40: 27 ; 41: 8,14 ; 43: 15 ; 58: 1)$. Jesaja praat van die "oorblysel van Israel", "die Heilige van Israel", "die Magtige van Israel" en die "lig van Israel" $(10: 20-22 ; 10: 20 ; 1: 24 ; 10: 17)$. God word nie met die staatkundige term "God van Juda" aangedui nie, maar wel met "God van Israel". Die begrip Israel is die draer van die tradisies oor die groot dade van God in die geskiedenis (Gerleman, 1971:785) en is daarom nie tot Juda beperk nie. Die begrip Israel omvat ook die lede van die Godsvolk in die Noordryk, wat staatkundig los van Juda was (vgl. Zobel, 1982:1006-1008).

\subsubsection{Die situasie by die skepping}

Ander nasies het hulle bestaan graag tenuggevoer na die skepping. Die Bybel daarenteen leer dat Israel nie 'n skeppingsgegewenheid is nie, maar eers later 
in die geskiedenis ontstaan het. Ook volkskap is nie 'n skeppingsgegewenheid nie, maar het eers later ontstaan. Volgens Genesis 1 het God by die skepping met die ander skepsele as verskillende groepe of soorte gehandel, maar met die mensdom as een geheel, as ' $n$ eenheid uit een man en vrou (vgl. Helberg, 1988:21).

\subsubsection{Die ontstaan van volke, hulle plek en dié van Israel}

Volke het enersyds onder die seën van die Here ontstaan, maar andersyds het dit wat organies moes plaasgevind het, tot 'n verskeurdheid gelei (Genesis 1011). Die basiese rede vir laasgenoemde is dat die mensdom hulle eenheid gesoek het deur administratiewe, organisatoriese, ekonomiese en ander faktore buite God om (die bou van 'n stad). Die fout is nie die soeke na eenheid nie, maar die feit dat dit op 'n onpersoonlike manier gedoen is deurdat daar nie met die verhouding met God gereken is nie. God antwoord op die gebeurtenis van Babel deur op die regte eenheid en die middel tot hierdie eenheid te wys. Hy gee nie 'n ander stad, byvoorbeeld Jerusalem, in Babel se plek nie, maar sy oplossing is deur en deur persoonlik. Hy sal die eenheid deur ' $n$ persoon, Abraham, bemiddel. Dit sal gebeur volgens mense se persoonlike verhouding tot God: "Ek sal seën wie jou seën en hom vervloek wat jou vervloek. In jou sal al die volke van die aarde geseën wees" (Gen. 12:3).

Die doel van die verbondsvolk se uittog uit Egipte was om Israel na God toe te bring (Eks. 19:4) sodat hulle volgens sy gebooie sal leef (Eks. 20). Hulle moes vir Hom 'n heilige volk wees, 'n koninkryk van priesters. Om 'n koninkryk van priesters te kon wees sluit onder meer in dat hulle die Woord van God aan die nasies moes bemiddel (Eks. 19:5-6; vgl. Helberg, 1988:79-80). Die boeke Jona en Rut laat 'n protes hoor teen 'n eng nasionalisme by Israel. God se genade strek veel wyer as net oor een volk. Volgens Jesaja 2 en Miga 4 sal al die nasies uiteindelik die wet van die Here soek en volgens Jesaja 19:25 sal Israel naas Egipte en Assirië die derde plek as geseënde volk van die Here inneem. Jesaja 40 e.v. getuig van God se universele mag en verlossing vir die nasies wêreldwyd.

\subsubsection{Die nuwe Israel as uitverkore volk}

Christus sê dat Hy alle mag in die hemel op die aarde ontvang het; daarom ontvang sy apostels die opdrag om die evangelie aan al die nasies te verkondig en om die mense wat glo te doop in die Naam van die Vader en die Seun en die Heilige Gees (Matt. 28:19-20). Met Pinkster word die Heilige Gees uitgestort en word die universaliteit van die kerk duidelik geopenbaar (Hand. 2). Romeine 9-11 verduidelik hoe die gelowige Godsvolk of Kerk voortaan die volk van God is en hoe die gelowiges in Israel daarby ingelyf word. 


\subsection{Die betekenis van die land van Israel in die Ou Testament}

Die beloofde land was 'n nasionale entiteit, maar met relatiewe waarde, soos uit die volgende aspekte sal blyk:

\subsubsection{God is nie landgebonde nie}

Die gode van die volke met wie Isnael in aanraking gekom het, soos die Kanaäniete, was natuurgode; daarom is die godheid en die land baie sterk met mekaar vereenselwig. Die god se mag was prakties tot die bodem beperk. Ons hoor dan ook van 'n Baäl-Hazor en van 'n Baäl-Hermon (2 Sam. 13:23; Rigt. 3:3). Daarteenoor word God nooit deur die Bybel die God van die land of van enige plek genoem nie. (In 2 Kon. 17:26 e.v.; 18:34 e.v.; 2 Kron. 32:19 word die woord "die God van Jerusalem" 'n heiden in die mond gelê; en in Genesis is daar duidelik 'n probleem met die teks; vgl. Van Selms, 1967:116.) God word wel die God van persone genoem: "die God van Abraham//sak/Jakob" (Gen. 28:23; Eks. 3:16) en "die God van Israel" (2 Sam. 7:25-26). Hierdie besondere verhouding rus op verkiesing en verbond (Gen. 12, 15, 17; Eks. 19).

\subsubsection{Die land is nie 'n skeppingsgegewe nie}

Dit is met Israel se land net so gesteld soos met sy volkskap. Anders as by die heidene word die land nie deur die Bybel as 'n skeppingsgegewe gesien nie. Israel is nie in die land gebore nie, maar was 'n volk voordat hy 'n land gehad het en het die land in die loop van die geskiedenis ontvang. Die naam land van Kanaän, wat die land met sy oorspronklike inwoners verbind, kom in die $\mathrm{Ou}$ Testament dan ook meer voor as die naam land van Israel. Daar is volgens die Bybel wel 'n noue verband tussen die mens en die aarde: die mens is uit die aarde geskep. Hy is egter nie uit die aarde gebore nie, maar God het self vir hom die lewensasem ingeblaas (Gen. 2:6). By sy skepping is die mens in 'n tuin geplaas; nie op die wye aarde soos op 'n oewerlose see nie, maar op 'n bepaalde plek. Die mens kon daardie plek hanteer en was daar geborge. Die taak wat hy van God gekry het, was egter nie geografies beperk nie, maar was universeel - hy moes die aarde bewerk (Gen. 1:28).

\subsubsection{Tuin van Eden, vreemdelingskap en land}

Weens die mens se sonde in die tuin van Eden het hy 'n vreemdeling geword. Sy vreemdelingskap raak sy verhouding met God en daarom ook sy verhouding tot die aarde. Voortaan sou die aarde dorings en distels voortbring. By die roeping van Abraham kry die mens die vooruitsig van die beloofde land as simbool van die herstelde verhouding met God. Die land is dus 'n simbool van die verlore tuin van Eden; daarom het die beloofde land ' $n$ besondere betekenis en spreek dit van 'n lewe van rus en vrede. Tog het die land 'n relatiewe 
betekenis wat blyk uit die volgende: die aartsvaders bly vreemdelinge in die beloofde land. Die land bly sterk 'n saak van die toekoms, van belofte. God stel Homself bekend as: "Ek is die Here jou God wat jou uit Egipte, uit die plek van slawerny, bevry het" (Eks. 20:2). Hy stel Homself egter nie bekend as "die God wat jou in die beloofde land ingelei het" nie (Helberg, 1990:88).

Dit is belangrik om daarop te let dat Israel nie dadelik uit Egipte die beloofde land binnegelei is nie (Stek, 1978:133-165; Helberg, 1990:31). Tussen die uittog en die intog staan Sinai waar Israel geleer word om Hom te dien volgens sy gebooie. Die klem val op 'n lewe in die regte verhouding tot God en die naaste; die plek is sekondêr. Sinai word nie 'n plek waar byeenkomste gehou word of waarheen pelgrimstogte onderneem word nie. In hierdie stadium was Israel reeds 'n volk, nog voordat hulle die land Kanaän ingegaan het (vgl. Hosea 11:1 en 12:14). Toe hulle later in ballingskap was, het hulle die verlies van die land deurstaan sonder om iets wesenliks van hulle bestaan as Godsvolk in te boet. Tog was daar gedurig 'n hunkering om na die land toe terug te keer. Die land het dus wel 'n belangrike maar ondergeskikte plek ingeneem. Gaandeweg het die stad Jerusalem die plek van die beloofde land ingeneem en is die verlange en vreugde gerig op Jerusalem as stad van God. Dit het egter nie om die stad self gegaan nie maar om die besondere teenwoordigheid van God waarvan die stad 'n simbool was (Eseg. 48:35; Clements, 1980:107-108; Helberg, 1990:79-81). In die Nuwe Testament is daar nog 'n verdere verskuiwing van die land en selfs van Jerusalem af weg na die nuwe Jerusalem, wat van bo af neerdaal (Op. 21:1-2; vgl. ook Matt. 5:5 oor die verwagting van die nuwe aarde, en Jes. 65:17-25 oor die nuwe hemel en die nuwe aarde).

\subsection{Die situasie rondom volkskap en land in die Nuwe Testament}

In die Nuwe Testament word die belang van land/plek nog verder gerelativeer, soos uit die volgende blyk:

\subsubsection{Jesus se geboorte en optrede}

Jesus Christus is nie in die gesiene stad Jerusalem gebore nie, maar in die onaansienlike Bethlehem. Hierdie plek bly ook daarna onaansienlik. In die Nuwe Testament het plekke wel betekenis, soos blyk uit die feit dat die plekke waar Jesus opgetree het, by name genoem word. Jesus se koms was nie net 'n geestelike gebeurtenis nie. Die plekke het egter slegs betekenis weens die beloftes en omdat Jesus daar opgetree het, en nie uit hulleself nie. Hulle kry ook nie daarna sodanige betekenis nie. Weens die kruisiging van Jesus verloor Jerusalem sy belangrike betekenis as godsdienstige sentrum en bly slegs 
belangrik as die beginpunt vanwaar die evangelie versprei. Die persoon van die opgestane Jesus self, nie 'n geografiese faktor nie, word nou die middelpunt.

\subsubsection{Die Nagmaal, uitstorting van die Heilige Gees en die gebed}

Anders as in die Ou-Testamentiese Pasga wat deur die Nagmaal vervang word, speel land in die Nagmaal geen rol nie (Matt. 26:26-30). Die Nagmaal hoef nie op ' $n$ bepaalde plek gevier te word nie: die bepalende faktor is die gemeenskap met Christus en met die gelowiges. Die fokus verskuif ook vanaf die eksterne vyand, soos Egipte of Rome, na die vyand in eie kring en eie boesem (Judas, Petrus; vgl. Helberg, 1990:121).

Ook by die uitstorting van die Heilige Gees speel land geen rol nie. Die Gees word nie op 'n land uitgestort nie, maar op persone en dan nie om hulle aan die land te verbind nie, maar aan Christus en sy gelowiges. Ook in die gebed wat Christus ons geleer het, het die land geen plek nie, behalwe implisiet onder die bede om die daaglikse brood, dit wil sê as deel van die gewone daaglikse behoeftes. Alle klem val op die eer van God en diens in sy koninkryk - 'n klemplasing wat van 'n ander aard is as dié van 'n aardse koninkryk op 'n aardse plek (Matt. 5).

\subsubsection{Die land by Paulus}

By Paulus is daar geen fokus op die land nie, wel op Christus. Anders as die aartsvaders wat by hulle sterwe verlang om saam met hulle vaders in die familiegraf begrawe te word, verlang Paulus om by Christus te wees ( 2 Kor. 5; Davies, 1974:213, 220). Die belofte is nou vervul. Die persoon van Christus is heeltemal sentraal en alles word gesien as ondergeskik aan Hom en in sy diens; daarom is ons vaderland en burgerskap in die hemel, waarvandaan ons Hom verwag (Fil. 3:20; vgl. Strecker, 1983:196-199).

\subsubsection{Die waarde van materiële dinge in die Nuwe Testament}

Materiële dinge het betekenis in die Nuwe Testament, soos bewys deur die feit dat die Woord mens geword het. Hierdie betekenis is egter relatief, dienend (vgl. 2.5.4 en Matteus 6:19-34). Die relatiewe betekenis geld ook van volkskap en land in die algemeen. 'n Christen word dus nie uit sy natuurlike verhoudinge uitgeruk nie. Verlossing beteken nie verlossing uit 'n mens se volk/land nie, maar verlossing in jou volk/land (Eichrodt, 1967:254). Tog verander die Christen se perspektief op sy volk en op die volke in die algemeen. Daar is nie plek vir eksklusiwiteit of selfgesentreerdheid van die volk nie. Die Christen sien sy volk nie op sigself nie, maar as diensbaar aan die universele Christus en sy universele doel. Volke bly tot aan die einde bestaan en materiële dinge het ook waarde na die wederkoms van Christus, soos daaruit 
blyk dat daar nie net 'n nuwe hemel kom nie, maar ook 'n nuwe aarde. 'n Plant wat uit die koringkorrel opkom, sal egter totaal anders lyk as die koringkorrel; so sal die liggaam na die opstanding totaal anders wees as tans (1 Kor. 15:37-38). Dieselfde geld vir volk en land. Die huidige volkskap en land het dus relatiewe waarde. Verder is, sedert die koms van Christus, die spesiale betekenis van Israel as volk en van die land vervul en verby (vgl. Verhoef, 1967:129).

\subsubsection{Die basiese faktor in verband met kerkwees}

Die een basiese faktor in verband met die volk van God is die geloof in Jesus Christus (Rom. 8:12-25; Gal. 3:27-29; 4:1-7). Dit is die enigste basiese norm in verband met die lidwees van die kerk. Alle ander oorwegings is praktiese oorwegings wat die doel van die een liggaam van Christus moet dien en dit nie in die weg mag staan nie. Die eenheid in Christus en sy liggaam, in diens van die koninkryk van God, is die allesbeheersende faktor in die lewe van die Christen.

\subsection{Samevatting en gevolgtrekking}

In die Ou Testament het Israel se volkskap en die land wat hulle bewoon het 'n besondere betekenis gehad. Tog was dit toe al duidelik dat dit 'n relatiewe betekenis is. Die uiteindelike doel was dat Israel die instrument is, of liewer die dienaar, sodat al die volke van die aarde in die seën sal deel. Israel was in die eerste plek 'n geestelike en nie 'n nasionale entiteit nie. Hoe belangrik die land ook al was, dit was steeds van sekondêre belang - voorop staan God se verhouding met mense. In die Nuwe-Testamentiese bedeling is die besondere betekenis van Israel as uitverkore volk en van die beloofde land vervul en uitgedien. Die allesbeheersende faktor is die koninkryk van God waaraan gelowiges uit alle volke deel het en wat van 'n heeltemal ander aard is as 'n aardse koninkryk met 'n aardse volk en land. Volkskap en land het nog betekenis, soos wat materiële dinge en behoeftes het, maar dit het geen spesiale betekenis nie en staan ten volle in diens van die koninkryk van God. In die lig van hierdie uiteensetting word die resultate van die ondersoek wat gedoen is, beskryf en bespreek.

\section{Ondersoek na die gebruik van die Ou Testament deur predikante en ander lidmate van die Gereformeerde Kerke}

Gedurende 1992 het die Departement Ou Testament van die PU vir CHO 'n ondersoek geloods na die gebruik van die Ou Testament deur predikante en ander lidmate van die Gereformeerde Kerke in Suid-Afrika. Hiervoor is 'n ewekansige steekproef geneem van predikante van die Kerke. Sewe en vyftig 
predikante het die vraelys ingevul. Daar is ook op 'n ewekansige wyse 'n aantal gemeentes geselekteer en uit elke gemeente 'n ewekansige steekproef op lidmate gedoen. Twee honderd agt en sewentig vraelyste is van lidmate ontvang. In die vraelyste is die persoonlike besonderhede van die respondente gevra en verder is daar gekonsentreer op die gebruik van die Ou Testament deur die predikante en lidmate. Waardevolle hulp in die opstel van die twee vraelyste en die verwerking van die antwoorde is gebied deur prof. H.S. Steyn en ander personeel van die Statistiese Konsultasiediens van die PU vir CHO. ${ }^{1}$

In die vraelys wat aan predikante gestuur is, was daar 27 vrae. Die eerste vier vrae het gehandel oor die ouderdom, dienstydperk en kwalifikasies van die predikant asook die tipe gemeente wat bedien word (stad, groter of kleiner dorp). Vraag 5-12 het gehandel oor die predikant se gebruik van en voorkeure ten opsigte van die Ou Testament, soos uit watter Bybelboeke die meeste gepreek word, watter Bybelboeke by voorkeur in eie en groepsbybelstudie gebruik word en watter persentasie van die predikant se preke uit die $\mathrm{Ou}$ Testament gemaak word. Vraag 13-19 het gehandel oor die verhouding tussen die twee Testamente en die verstaan van die Ou Testament in die lig van die Nuwe Testament, met vrae oor die verhouding tussen die twee Testamente, die interpretasie van Messiaanse gedeeltes en die gebruik van tipologie. Vraag 2027 het gehandel oor wat die Ou Testament leer oor die bestaan en ontstaan van volke en die betekenis van 'n land en die betekenis van land en volk vir die hedendaagse kerk.

In die vraelys wat aan ander lidmate gestuur is, was daar 21 vrae. Die eerste vyf vrae het gehandel oor die ouderdom, geslag, kwalifikasies en beroep van die lidmaat, asook die tipe gemeente waaraan die lidmaat behoort (stad, groter of kleiner dorp). Vraag 6-12 het gehandel oor die lidmaat se gebruik van en voorkeure ten opsigte van die Ou Testament, soos uit watter Bybelboeke die meeste gelees word en tydens huisgodsdiens en eie Bybellees gebruik word en uit watter boeke by voorkeur na preke geluister word. Vraag 13-14 het gehandel oor die verhouding tussen die twee Testamente. Vraag 16-21 het gehandel oor wat die Ou Testament leer oor die bestaan en ontstaan van volke en die betekenis van 'n land en die betekenis van land en volk vir die kerk van vandag.

1 Die vraelys wat an predikante gestuur is, is 15 bladsye lank en die een vir die ander lidmate 9 bladsye. Dit is dus nie moontlik om die volledige vraelyste in hierdie artikel in te sluit nie. Belangstellendes kan egter 'n kopie van die vraelyste by die skrywers aanvra. 


\subsection{Die Ou Testament in die algemeen}

By sowel die predikante as die lidmate is daar navraag gedoen oor watter boeke van die Bybel hulle die graagste lees. Vir dié doel is die boeke in 'n aantal groepe verdeel. Die vyf boeke of groepe boeke wat die meeste deur predikante gelees word, is in voorkeurvolgorde die volgende: die Briewe van Paulus, die Evangelies, Psalms, die ander briewe in die Nuwe Testament en Handelinge. Wat die Ou Testament betref, was die rangorde die volgende: Psalms, Groot Profete, Pentateug, Klein Profete, Spreuke-Prediker-Hooglied, Samuel-Konings, Josua-Rigters-Rut, Job en Kronieke-Esra-Nehemia.

Wat die lidmate betref, was die eerste vyf boeke in voorkeurvolgorde die volgende: Psalms, die Briewe van Paulus, die Evangelies, Handelinge en Spreuke-Prediker-Hooglied. Wat die Ou Testament betref, is die volgorde Psalms, Spreuke-Prediker-Hooglied, Groot Profete, Samuel-Konings, JosuaRigters-Rut, Job, Klein Profete, Pentateug en Kronieke-Esra-Nehemia.

Wat die volgorde betref, is wat die Bybel as geheel betref, die plek van Psalms by die lidmate opmerklik. Dit is verder ook opmerklik dat Spreuke-PredikerHooglied by die lidmate onder die eerste vyf verskyn. Wat al die boeke van die Ou Testament betref, plaas sowel predikante as lidmate Psalms eerste. Verder is die plek van Spreuke-Prediker-Hooglied by die lidmate weer opvallend. Verder kan daarop gelet word dat die predikante die Pentateug derde plaas, terwyl dit by die lidmate agste uit nege is.

Die predikante is gevra uit watter boeke of groep boeke hulle die meeste preek. Die rangorde is die Evangelies, die Briewe van Paulus, die ander Briewe in die Nuwe Testament, Psahms en die Groot Profete. Wat die Ou Testament betref, is die rangorde Psalms, die Groot Profete, die Klein Profete, Pentateug, SamuelKonings, Josua-Rigters-Rut, Spreuke, Kronieke-Esra-Nehemia en Job. Uit hierdie gegewens is dit duidelik dat in sowel eie Bybellees as prediking die $\mathrm{Ou}$ Testament by predikante baie minder aan die orde kom as die Nuwe Testament. Wat die Ou Testament self betref, word veral gekonsentreer op die Psalms en die Groot Profete, terwyl die verhalende gedeeltes en die wysheidsliteratuur baie min aan die orde kom. Hierdie gegewens word bevestig deur die antwoorde op die vraag waar gevra is of daar groepe boeke is waaroor daar nog nooit gepreek is nie. Die boeke of groepe boeke wat hier die meeste vermeld word, is EsraNehemia-Kronieke, die Klein Profete en Spreuke-Prediker-Hooglied. Dieselfde patroon kom voor in die antwoorde op die vraag waar daar gevra is watter boeke of groepe boeke in die Ou Testament die predikante die meeste aanspreek. Die rangorde is Psalms, Groot Profete, Pentateug, Klein Profete, Samuel-Konings, Spreuke-Prediker-Hooglied, Josua-Rigters-Rut, Job en Kronieke-Esra-Nehemia. Die voorkeur van predikante word bevestig deur die antwoorde op die vraag waar daar gevra is na die eie voorkeur vir lees en preek 
ten opsigte van die vyf groepe. Die rangorde is Psalms, profetiese stof, verhalende stof, wysheidsliteratuur en wetsgedeeltes.

Daar is ook ondersoek ingestel na die lidmate se voorkeur ten opsigte van preke en eie Bybelstudie. By die vraag uit watter boeke en groepe boeke in die Bybel die respondente die graagste na preke luister, was die eerste vyf die Briewe van Paulus, die Evangelies, Handelinge, Psalms en die Groot Profete. Laaste was Kronieke-Esra-Nehemia en tweede laaste die Pentateug. Wat die Ou Testament betref, was die volgorde Psalms, Groot Profete, Spreuke-Prediker-Hooglied, Samuel-Konings, Job, Klein Profete, Josua-Rigters-Rut, die Pentateug en Kronieke-Esra-Nehemia.

Amper dieselfde volgorde kom voor in die antwoorde op die vraag watter boeke of groepe boeke in die $\mathrm{Ou}$ Testament die lidmate die meeste aanspreek. Die volgorde is Psalms, Spreuke-Prediker-Hooglied, Groot Profete, Job, SamuelKonings, Josua-Rigters-Rut, Kronieke-Esra-Nehemia, Klein Profete en Pentateug. Lidnate is ook gevra om aan te dui watter enkele boek hulle die meeste aanspreek. 76 het nie die vraag geantwoord nie. Van dié wat wel geantwoord het, het $35.97 \%$ Psalms genoem, 9.71\% Spreuke, $8.99 \%$ Job, 4.32\% Genesis, $2.52 \%$ Prediker en Jesaja en $2.16 \%$ Daniël. Op die vraag watter boeke al in huisgodsdiens betrek is, blyk iets van dieselfde patroon by die lidmate. Die volgorde is Psalms, Spreuke-Prediker-Hooglied, Groot Profete, Pentateug, Job, Samuel-Konings, Josua-Rigters-Rut, Kronieke-Esra-NehemiaEster en die Klein Profete. Wat die voorkeur vir eie lees uit die Ou Testament betref, is die volgorde Psalms, wysheidsliteratuur, profetiese stof, verhalende stof en wetsgedeeltes. As dit met die predikante se voorkeur vergelyk word, is dit opvallend dat wysheidsliteratuur tweede by die lidmate is maar vierde by die predikante. Wat die ander vier groepe betref, is die volgorde dieselfde.

Uit hierdie gegewens is dit duidelik dat die wetsgedeeltes van die Ou Testament by sowel die predikante as lidmate min aandag kry, dat Esra-NehemiaKronieke ook by albei groepe min aandag kry en dat die lidmate 'n voorkeur vir die wysheidsliteratuur het wat nie deur die predikante gedeel word nie. By lidmate is daar 'n duidelike voorkeur vir die Nuwe Testament en ten opsigte van die Ou Testament is daar ' $n$ voorkeur vir stof wat meer persoonlik van aard is, soos die digterlike en wysheidsliteratuur. Vir predikante dui die gegewens daarop dat hulle meer aandag kan gee aan die wysheidsliteratuur en dat hulle hulleself moet afvra hoekom Esra-Nehemia-Kronieke nie eintlik in hulle prediking funksioneer nie.

Die predikante is ook gevra on aan te dui watter persentasie van hulle preke hulle uit die Ou Testament maak. Uit die antwoorde blyk dat in die meeste gevalle die Ou Testament baie minder as die Nuwe Testament in die prediking 
aan die orde kom. Die persentasie van die predikante wat die vraag geantwoord het ten opsigte van die frekwensie van preke uit die Ou Testament (in persentasie van alle preke) is soos volg:

\begin{tabular}{|l|l|}
\hline $\begin{array}{l}\text { Persentasie preke uit } \\
\text { die O.T. }\end{array}$ & $\begin{array}{l}\text { Persentasie } \\
\text { predikante }\end{array}$ \\
\hline $50-60 \%$ & $16.36 \%$ \\
$40-50 \%$ & $1.82 \%$ \\
$30-40 \%$ & $43.64 \%$ \\
$20-30 \%$ & $34.55 \%$ \\
minder as 20\% & $3.64 \%$ \\
\hline
\end{tabular}

Uit hierdie gegewens blyk duidelik dat die grootste gedeelte van die predikante minder as $40 \%$ van hulle preke uit die Ou Testament maak (82\%), terwyl net meer as 'n derde minder as $30 \%$ van hulle preke uit die Ou Testament maak. Die grootste enkele groep is die $43.64 \%$ wat tussen $30 \%$ en $40 \%$ van hulle preke uit die Ou Testament maak. Indien die relatiewe lengte van die twee Testamente in gedagte gehou word (bykans drie tot een), is dit duidelik dat die afsonderlike boeke van die $\mathrm{Ou}$ Testament baie min aan die orde kom. Al wat feitlik relatief gereeld aan die orde kom, is die Psalms en die Klein en Groot Profete. Preke oor die verhalende stof, wysheidsliteratuur en die wette kom baie min voor.

Daar is by sowel lidmate as predikante ondersoek ingestel na die hantering van die sogenaamde Messiaanse gedeeltes van die Ou Testament.

Wat die verskyning van die Messias in die Ou Testament betref, is dit uit die ondersoek duidelik dat die meerderheid van die predikante daartoe geneig is om die Ou Testament met gemak direk Messiaans te interpreteer. Dit blyk duidelik uit die antwoorde op drie vrae in die vraelys aan predikante wat hiermee verband hou.

In antwoord op die vraag of die engel van die Here 'n verskyningsvorm van Christus in die Ou Testament is, het die predikante soos volg geantwoord: altyd $-28.57 \%$; dikwels $-44.64 \%$; soms $-19.64 \%$ en nooit $-7.14 \%$. In antwoord op die vraag of die Messiaanse gedeeltes van die Ou Testament Jesus Christus verkondig, was die antwoorde soos volg: $\mathrm{Ja}-81.82 \%$; nee $-1.82 \%$; soms $-18.18 \%$. 
Die predikante is ook gevra om aan te dui of sekere gedeeltes as direk Messiaans beskou moet word. Die volgende persentasie het by elk van die gedeeltes $J a$ geantwoord:

\begin{tabular}{|lr|lr|}
\hline \multicolumn{4}{|c|}{$\begin{array}{c}\text { Skrifgedeeltes wat deur predikante as } \\
\text { direk Messiaans beskou word }\end{array}$} \\
\hline \multicolumn{2}{|c|}{ Gen. 3:15 $-92.59 \%$} & Psalm 20 & $-11.11 \%$ \\
Deut. 18:15-22- $57.41 \%$ & Psalm 72 & $-20.37 \%$ \\
Job 19:25 $-59.26 \%$ & Psalm 89 & $-29.63 \%$ \\
2 Sam. 7:5-17- $-31.48 \%$ & Psalm 110 & $-83.33 \%$ \\
Jesaja 7 & $-68.52 \%$ & Miga 4 & $-57.41 \%$ \\
Jesaja 9:1-6 & $-92.59 \%$ & Miga 5 & $-83.33 \%$ \\
Jesaja 11 & $-85.18 \%$ & Psalm 45 & $-40.74 \%$ \\
Jesaja 53 & $-96.30 \%$ & Hooglied & $-20.37 \%$ \\
\hline
\end{tabular}

Wat opval, is die hoë persentasies ten opsigte van Genesis 3:15, Psalm 110, Jesaja 9, 11 en 53 en Miga 5.

Die lidmate is gevra of die engel van die Here 'n verskyningsvorm van Christus in die $\mathrm{Ou}$ Testament is. $28.29 \%$ het gesê altyd, $28.68 \%$ dikwels, $21.71 \%$ soms en $21.32 \%$ nooit. In vergelyking met die predikante het ongeveer dieselfde persentasie lidmate gesê altyd, maar 'n baie kleiner persentasie as wat by die predikante die geval was het dikwels gekies. In die lig van die bespreking in 2.2 is dit duidelik dat sowel die predikante as die ander lidmate geneig is om te gemaklik die Ou-Testamentiese Messiaanse gedeeltes direk Messiaans te interpreteer.

\subsection{Die Ou Testament en die volkslewe}

In die vraelys is daar ook aandag gegee aan sake wat met die predikante en ander lidmate se siening van die Ou Testament en die volkslewe verband hou.

Sowel die predikante as die lidmate is gevra waaraan die ontstaan en bestaan van volke toegeskryf kan word. Verskillende moontlikhede is genoem, waarvan een of meer gekies kon word. Die keuses was soos volg: 


\begin{tabular}{|c|c|c|c|}
\hline & \multicolumn{3}{|c|}{$\begin{array}{c}\text { Waaraan kan die ontstaan en bestaan van volke } \\
\text { toegeskryf word? }\end{array}$} \\
\hline & Moontlikheid & Predikante & Lidmate \\
\hline 1. & Skeppingsordinansie & $78.95 \%$ & $25.76 \%$ \\
\hline 2. & Gevolg van die sondeval & $1.75 \%$ & $21.59 \%$ \\
\hline 3. & $\begin{array}{l}\text { Natuurlike ontwikkeling } \\
\text { in die skepping }\end{array}$ & $82.46 \%$ & $15.53 \%$ \\
\hline 4. & $\begin{array}{l}\text { Skeppingsordinansie en } \\
\text { a.g.v. die sondeval ( } 1 \text { en } \\
\text { 2) }\end{array}$ & $71.93 \%$ & $13.26 \%$ \\
\hline 5. & $\begin{array}{l}\text { Skeppingsordinansie en } \\
\text { 'n natuurlike } \\
\text { ontwikkeling in die } \\
\text { skepping ( } 1 \text { en } 3 \text { ) }\end{array}$ & $96.49 \%$ & $12.12 \%$ \\
\hline 6. & $\begin{array}{l}\text { 'n Gevolg van die } \\
\text { sondeval en 'n natuurlike } \\
\text { ontwikkeling in die } \\
\text { skepping ( } 2 \text { en } 3 \text { ) }\end{array}$ & $80.70 \%$ & $11.36 \%$ \\
\hline
\end{tabular}

Die predikante het gewoonlik meer as een van die moontlikhede gemerk. Hier moet die aandag gevestig word op die hoë persentasie wat die moontlikheid van skeppingsordinansie op sy eie of in kombinasie met 'n natuurlike ontwikkeling in die skepping en as ' $n$ gevolg van die sondeval as keuse aandui. Ook natuurlike ontwikkeling in die skepping kry goeie ondersteuning, terwyl 'n mens sou dink dat moontlikheid 1 moontlikheid 2 en 3 uitsluit. Die lidmate het weer elk net een moontlikheid gemerk, sodat 'n vergelyking nie so gemaklik moontlik is nie. Tog het skeppingsordinansie op sy eie of in kombinasie met die ander twee moontlikhede meer as die helfte van die lidmate se steun gekry. Uit die voorafgaande bespreking blyk dit egter dat nie Israel nie, maar die nasies rondom Israel hulle bestaan na die skepping teruggevoer het. Volgens die Ou Testament is volkskap nie 'n skeppingsgegewe nie, maar dit is duidelik dat die meerderheid lidmate en predikante in die Gereformeerde Kerke anders dink.

Die predikante en lidmate is gevra wat die deurslaggewende indelingsbeginsels op kerklike gebied volgens die Ou Testament is. Hiermee is bedoel watter beginsels gebruik moet word wanneer besluit word hoe die lidmaatskap van plaaslike kerke en die samestelling van meerdere vergaderings gereël moet 
word, met as agtergrond die etnies-gefundeerde indeling wat in die GKSA praktyk is. In die bespreking in 2.5 .5 is die aandag daarop gevestig dat geloof die basiese faktor is wat kerklidmaatskap bepaal. $45.45 \%$ van die predikante het gesê volke, geen rasse en $54.55 \%$ nie volke of rasse nie. Wat die lidmate betref, het $80.23 \%$ geantwoord volke, $4.94 \%$ rasse en $14.83 \%$ nie een van die twee nie. Die aansienlik groter persentasie lidmate wat volke aangedui het, kan waarskynlik gesien word as bewys dat besluite van die Sinodes van die Gereformeerde Kerke in hierdie verband nie tot lidmate deurgedring het nie. Die persentasie predikante wat genoemde siening het, is ook taamlik hoog.

Die predikante is gevra watter is geldige indelingsbeginsels volgens die $\mathrm{Ou}$ Testament. Hiermee word dieselfde bedoel as die gegewens wat in die vorige paragraaf uiteengesit is. Wat was die maatstawwe waarvolgens Israel van die ander volke/groepe onderskei is? $70.37 \%$ van die predikante het gesê volke, geen rasse en $29.63 \%$ nie volke of rasse nie. Die bedoeling met hierdie en die vorige vraag was om te probeer vasstel of 'n rasgebonde indeling van mense sterk leef onder lidmate van die GKSA en of hulle insien dat selfs volke nie as finale maatstaf vir die verdeling van mense in groepe gebruik kan word nie. Die lidmate is gevra of ' $n$ hedendaagse mens wat ' $n$ lid is van een volk na 'n ander volk kan oorgaan volgens die Ou Testament. $41.96 \%$ het gesê $J a$ en $58.04 \%$ Nee. Hierdie antwoorde dui daarop dat 'n volksgebonde siening sterk leef onder die lidmate van die GKSA en dit is opvallend in die lig van die feit dat as mense nie van een volk na 'n ander mag oorgaan nie, die Afrikanervolk nie sou kon ontwikkel het uit die samevoeging van mense uit verskillende volke nie.

\begin{tabular}{|l|r|r|}
\hline \multicolumn{3}{|c|}{ Watter sake lê op die terrein van die kerk? } \\
\hline Onderwerp & Predikante & Lidmate \\
\hline Prediking oor politieke sake & $80.36 \%$ & $20.86 \%$ \\
Partypolitiek & $1.79 \%$ & $1.80 \%$ \\
Vermaning van regering & $83.93 \%$ & $38.49 \%$ \\
Vermaning van politieke & $73.21 \%$ & $23.74 \%$ \\
partye & & \\
Voorbidding vir politieke & $98.21 \%$ & $86.69 \%$ \\
leiers & & \\
Voorbidding vir weermag & $82.14 \%$ & $57.19 \%$ \\
Propagering van beleids- & $3.57 \%$ & $2.52 \%$ \\
verandering van regering & & \\
\hline
\end{tabular}

Die predikante en lidmate is gevra na sake wat op die terrein van die kerk lê. Bostaande tabel en persentasies dui die verskillende moontlikhede aan. 
Ten opsigte van sommige van die aangeleenthede is daar belangrike verskille tussen die standpunte van predikante en lidmate. Dit is baie duidelik dat die lidmate baie minder betrokkenheid by politieke aangeleenthede wil hê as die predikante. Dat $80 \%$ van die predikante en slegs $20 \%$ van die lidmate oordeel dat prediking oor politieke sake in orde is, dui op verskillende sienings oor wat met politiek bedoel word. Dit sou kon beteken dat die predikante 'n onderskeid kan maak tussen sake wat op partypolitieke terrein lê en dit wat met breëre landspolitiek te doen het, terwyl die lidmate óf nie daardie onderskeid maak nie, of in elk geval wil hê dat die predikante op meer 'geestelike' sake moet konsentreer.

Die predikante en lidmate is gevra watter van 'n aantal sake wat op Israel in die Ou Testament van toepassing was, vandag ook op die Afrikanervolk van toepassing is. Die volgende persentasie predikante en lidmate het elk van die moontlikhede gemerk:

\begin{tabular}{|l|l|l|}
\hline $\begin{array}{l}\text { Watter aspekte wat met Israel verband hou, is ook van } \\
\text { toepassing op die Afrikanervolk? }\end{array}$ \\
\hline Onderwerp & Predikante & Lidmate \\
\hline Verkiesing & $8.93 \%$ & $17.27 \%$ \\
Gawe van 'n land & $26.79 \%$ & $30.22 \%$ \\
Afsondering van ander volke & $3.57 \%$ & $11.51 \%$ \\
Unieke roeping & $21.43 \%$ & $32.01 \%$ \\
Besondere band met God & $25.00 \%$ & $55.76 \%$ \\
Geeneen van die voorafgaande & $55.36 \%$ & $19.78 \%$ \\
\hline
\end{tabular}

Dit is duidelik dat die predikante baie meer genuanseerd oor hierdie onderwerpe nadink as die lidmate. Dit is veral opmerklik ten opsigte van verkiesing, afsondering van ander volke, unieke roeping en die besondere band met God. Wat die predikante betref, is die relatief hoë persentasie ten opsigte van gawe van 'n land en die besondere band met God opmerklik.

Die predikante en lidmate is gevra om aan te dui hoe belangrik 'n land volgens die Ou Testament is vir die bestaan van 'n volk. Die keuses was soos volg: 


\begin{tabular}{|l|l|c|}
\hline \multicolumn{3}{|l|}{$\begin{array}{l}\text { Hoe belangrik is 'n land vir die bestaan van } \\
\text { 'n volk - volgens die O.T.? }\end{array}$} \\
\hline Moontlikheid & Predikante & Lidmate \\
\hline Onontbeerlik & $20 \%$ & $32.09 \%$ \\
Baie belangrik & $20 \%$ & $33.58 \%$ \\
Belangrik & $32.73 \%$ & $21.27 \%$ \\
Irrelevant & $10.91 \%$ & $5.60 \%$ \\
Van min belang & $16.36 \%$ & $7.46 \%$ \\
\hline
\end{tabular}

Albei groepe is ook gevra hoe belangrik hulle tans 'n land beskou vir die voortbestaan van die Afrikanervolk. Die keuses was soos volg:

\begin{tabular}{|l|r|r|}
\hline \multicolumn{3}{|c|}{$\begin{array}{c}\text { Hoe belangrik is 'n land vir die } \\
\text { voortbestaan van die Afrikanervolk? }\end{array}$} \\
\hline Moontlikheid & Predikante & Lidmate \\
\hline Onontbeerlik & $21.43 \%$ & $29.48 \%$ \\
Baie belangrik & $8.93 \%$ & $30.22 \%$ \\
Belangrik & $32.14 \%$ & $22.01 \%$ \\
Irrelevant & $12.50 \%$ & $7.84 \%$ \\
Van min belang & $21.43 \%$ & $10.45 \%$ \\
\hline
\end{tabular}

Dit is duidelik dat in die geval van bogenoemde twee vrae die lidmate baie sterker oor die belang van 'n land voel as wat die geval by die predikante is. Ten opsigte van die sake wat met land en volk te doen het, dink predikante duidelik meer genuanseerd as die lidmate. Predikante kan dit dus oorweeg om ten opsigte van hierdie sake duidelike leiding aan lidmate te gee, ook in die prediking.

\section{Samevattende bespreking}

Dit is duidelik dat die Ou Testament in sowel die prediking as die persoonlike Bybelstudie van predikante en lidmate minder aan die orde kom as die Nuwe Testament. By die persoonlike Bybelstudie van lidmate kom Psalms eerste aan die orde, terwyl dit opmerklik is dat die wysheidsliteratuur ook by die lidmate 'n belangriker plek inneem as by die predikante. Wat prediking uit die $\mathrm{Ou}$ Testament betref, kom veral die profetiese boeke en Psalms aan die orde. Kronieke, Esra en Nehemia neem by sowel lidmate as predikante die laaste plek 
in. Uit die belangstelling wat lidmate in die wysheidsliteratur het, kan predikante aflei dat hulle meer daaroor kan preek as wat wel die geval is. Wat prediking uit die Ou Testament betref, is dit opvallend dat meer as $80 \%$ van die predikante minder as $40 \%$ van hulle preke uit die Ou Testament maak, terwyl net meer as 'n derde selfs minder as $30 \%$ van hulle preke uit die Ou Testament maak. Hierdie ondersoek beklemtoon die noodsaaklikheid daarvan dat predikante selfondersoek behoort te doen oor die frekwensie en wyse waarop die Ou Testament in hulle prediking aan die orde kom. Om die volle raad van God te verkondig, is dit noodsaaklik dat die kanon in sy volle omvang in die prediking aan die orde kom.

Wat die verskyning van die Messias in die Ou Testament betref, is dit duidelik dat die meerderheid predikante wat aan die ondersoek deelgeneem het, daartoe geneig is om die $\mathrm{Ou}$ Testament maklik direk Messiaans te interpreteer en dus nie die konkreet-historiese aard van die Ou Testament tot sy reg laat kom nie.

Wat die Ou Testament en die volkslewe betref, is dit merkwaardig dat so 'n groot persentasie van sowel die predikante as die lidmate die bestaan van volke aan 'n skeppingsordinansie verbind het. Uit die bespreking (vergelyk 2.3.2 en 2.3.3) is dit duidelik dat dit juis die een saak was wat Israel van die volke onderskei het, naamlik dat Israel nie hulle bestaan na die skepping teruggevoer het nie. Die Ou Testament maak dit duidelik dat volke nie 'n skeppingsgegewe is nie, maar die meerderheid van die predikante en lidmate wat aan die ondersoek deelgeneem het, dink anders. Hierdie siening word ook gereflekteer in die antwoord op die vraag wat die deurslaggewende indelingsbeginsels op kerklike gebied is: $45 \%$ van die predikante en $80 \%$ van die lidmate het volke gekies. Die feit dat soveel minder predikante hierdie keuse uitgeoefen het, toon wel dat hulle meer genuanseerd hieroor nadink as die lidmate. Volkskap is 'n saak wat praktiese implikasies kan hê, maar dit kan nie beskou word as die deurslaggewende verdelingsbeginsel op kerklike gebied nie.

Wat die toepassing van beginsels uit die Ou Testament op vandag se situasie betref, is dit opmerklik dat ' $n$ baie groot persentasie lidmate nie geoordeel het dat prediking oor politieke sake op die terrein van die kerk lê nie $(80 \%)$, teenoor 'n klein persentasie predikante (20\%). Ten opsigte van hierdie aspek mag dit dalk nog 'n terrein wees waar predikante meer genuanseerd dink, en onderskei tussen sake wat met landspolitiek te doen het en dié wat op die gebied van suiwer party-politiese aangeleenthede lê. Die predikante dink ook meer genuanseerd oor die sake uit die Ou Testament wat soms op die Afrikaner van toepassing gemaak word - sake soos verkiesing en die gawe van 'n land. Hierdie toedrag van sake getuig daarvan dat daar wel leiding van die predikante na die lidmate in dié verband kan uitgaan. 


\section{Bibliografie}

BRIGHT, J. 1967. The Authority of the Old Testament. London : SCM.

CLEMENTS, R.E. 1980. Isaiah and the Deliverance of Jerusalem: A Study of the Interpretation of Prophecy in the Old Testament. JSOT Supp. 13. Sheffield : JSOT Press.

DAVIES, W.D. 1974. The Gospel and the Land. Los Angeles : University of California Press.

EICHRODT, W. 1967. Theology of the Old Testament I. London : SCM.

GERLEMAN. 1971. Jisra'el Israel. (In THAT I. München : Kaiser. p. 782785.)

HELBERG, J.L. 1983. Verklaring en prediking van die Ou Testament. Potchefstroom : Potchefstroomse Teologiese Publikasies.

HELBERG, J.L. 1988. Die Here regeer. Pretoria : NGKB.

HELBERG, J.L. 1990. Die verbondsvolk se verhouding tot sy land. Potchefstroom : PU vir CHO, Dept. Sentrale Publikasies.

STEK, J. 1978. Salvation, Justice and Liberation in the Old Testament. Calvin Theological Journal, 13(2):133-165.

STRECKER, G. 1983. Das Land Israel in frühchristlicher Zeit. (In Strecker, G., red. Das Land Israel in biblischer Zeit. Jerusalem Symposium 1981 der Hebraïschen Universität und der George August-Universität. Göttingen : Vandenhoeck \& Ruprecht. p. 188-200.)

VAN SELMS, A. 1967. Genesis. I. Nijkerk: Callenbach. (Prediking van het Oude Testament.)

VERHOEF, P.A. 1967. Israel in die krisis. Pretoria : NGKB.

ZOBEL, H.J. 1982. jisra'el. (In ThWAT III. Stuttgart : Kohlhammer. p. $986-1092$. 
